\title{
Assembling an Army: Considerations for Just War Theory ${ }^{1}$
}

(Forthcoming in Journal of Global Ethics)

\section{Section 1: Introduction}

Just war theory has, historically, aimed to provide guidelines by which nations may judge the moral permissibility of engaging in and carrying out a war. Along the way, problems regarding the resort to war as well as those regarding the execution of war have yielded differing sets of principles. Those associated with the former constitute the body of doctrine now referred to as jus ad bellum and the latter jus in bello. There has been much debate recently among just war theorists regarding how best to interpret the relationship between these two divisions of just war theory. The traditional view, whose most prominent contemporary advocate is Michael Walzer, holds that these sets of principles are to be treated entirely independently of one another. That is, judgments regarding ad bellum issues are not seen as having any impact on judgments regarding in bello questions. This view arises in part from the widely accepted position that, within the context of war, combatants on each side of a conflict are to be treated as moral equals regardless of the permissibility of the war that each is fighting. This traditional view has been forcefully challenged in recent work by Jeff McMahan (2009) who argues that combatants who fight on behalf of a nation engaged in an unjust war do not have the same moral rights as those

\footnotetext{
${ }^{1}$ I am grateful to many people for their helpful feedback on earlier drafts of this manuscript. In particular, I would like to thank Massimo Renzo for his insightful comments on a previous version, the faculty at the Center for the Study of Ethics in the Professions at the Illinois Institute of Technology (and especially Michael Davis) for their commentary during a presentation of some of this material, the participants at the 2013 meeting of the Association for Political Theory for many thoughtful questions and objections, and, finally, the editors and referees at Journal of Global Ethics whose comments and criticisms have helped make this a much stronger paper than it otherwise would have been.
} 
fighting a just war. ${ }^{2}$ If McMahan is correct, and I think that he is, then we have reason to adopt a broader interpretation of the traditional just war doctrines which is sensitive to the potential interdependence of ad bellum and in bello principles.

My concern in what follows is to further broaden the way in which these categories are interpreted by drawing attention to an issue in just war theory which has been largely overlooked by philosophers - namely, the impact that the conditions under which an army ${ }^{3}$ is assembled are liable to have on the judgments that are made with respect to traditional ad bellum and in bello principles. In other words, I will be interested in answering the following question: What role, if any, ought the method used to assemble an armed force play in our judgments regarding the justice of a war? It seems to me that the way in which an army is assembled can significantly alter such judgments, and the aim of this paper, therefore, is to defend the notion that the requirement of just assembly is an essential part of any deliberation regarding the justice of a particular conflict. This requirement can be stated as follows:

\section{Principle of Just Assembly 4}

In order for a nation to engage in a just war, it must do so with an armed force that has been justly assembled.

A principle such as this is important because it helps to bridge the gap between philosophical approaches to just war theory and a significant portion of work being done

\footnotetext{
2 These views are not new developments in the history of just war theory. What I have here referred to as "the traditional view" was developed in the eighteenth century by Christian von Wolff and Emer de Vattel, and the sort of view espoused by McMahan was long considered orthodoxy and can be found in some form in the works of Grotius and Aquinas. (Reichberg 2008; Bazargan 2013). My focus will be on Walzer and McMahan for the simple reason that their views have been the most influential in the contemporary just war literature. ${ }^{3}$ I will use "army" and "armed force" interchangeably throughout the essay. These should both be understood to refer to all branches of a nation's military. Likewise, I will use the term "soldier" to refer to members of all branches of the military. The term will be used as a sort of placeholder for the sake of brevity and is not meant as a slight to any members of other branches of the military who prefer some other moniker.

${ }^{4}$ This seems to me the best term for the present discussion, though I acknowledge that it has the potential for confusion. Throughout this paper I use it to refer solely to the method of assembling an armed force or raising an army.
} 
on the moral permissibility of various modes of military assembly. For example, considerable work has been done on the moral permissibility of both conscripted ${ }^{5}$ and privately contracted armed forces, ${ }^{6}$ but this work has rarely been brought to bear on traditional just war doctrine in any systematic way. As James Pattison puts it, "[W]e need a richer, broader account of just war theory which is more sensitive to the issues surrounding the legitimacy of the military ... This should ensure that the judgments of the justice of particular wars are more accurate and should lead to a more sophisticated analysis of the ongoing legitimacy of the military." (Pattison 2011, p. 150) The present paper is intended to be a first step toward this broader account.

In order to proceed, I will begin by sketching one plausible argument in favor of the principle of Just Assembly. There may well be other arguments that could be offered, but given the tremendous risk that soldiers undertake by engaging in armed conflict, a natural starting point for such an argument is to focus on this risk and whether it is voluntarily assumed. Call this the Argument from Consent.

(1) It is unjust to cause an individual to risk her life without her consent.

(2) If a nation engages in military conflict, it risks the lives of its military members.

(3) If a nation's military members do not consent to participate in a conflict, then by engaging in said conflict the nation risks the lives of its military members without their consent.

(4) Therefore, it is unjust for a nation to engage in military conflict without the consent of the members of its military.

The Argument from Consent is, I think, sufficiently plausible to motivate further investigation into the connection between assembly and just war considerations.

\footnotetext{
${ }^{5}$ See, for example, Galston (2003); Steiner (2006); Gorr (1983)

${ }^{6}$ See, for example, Lynch \& Walsh (2000); Fabre (2010); Pattison (2011). For one example of an examination of the implications of mercenary forces for just war principles, see Pattison (2010).
} 
Nonetheless, considerable defense is required before the Argument from Consent can be seen as providing a positive case for the connection between Just Assembly and traditional just war principles. Specifically, there are at least two clear paths that one might take in rejecting the argument. First, one might object by attempting to show that premise (1) is false. There are several ways in which this might be done, and Section 2 will be devoted to identifying and responding to these objections. Doing so will allow us to arrive at a working definition of what, precisely, Just Assembly consists in. Second, even if premise (1) is true, one might still reject the Argument from Consent by claiming that the conclusion simply does not follow. That is, it might be claimed that even if it is unjust for a nation to undertake certain methods of raising an army, this is not reason to claim that the war itself is unjust. In Section 3, I address this worry by attempting to draw out a number of connections that may exist between the traditional just war doctrine and considerations of the circumstances under which an army is assembled. If these connections are indeed present and sufficiently strong, then this will suffice to show that the conclusion of the argument does indeed follow.

\section{Section 2: Just Assembly and the Role of Consent}

The Argument from Consent is, I think, the strongest argument in favor of the principle of Just Assembly. However, given that the argument hinges on the claim that a justly assembled force is one which ensures the consent of its soldiers, an extended discussion of this claim is needed. There may, indeed, be a number of reasons to think that consent is not a necessary feature of a justly assembled army, and I will consider some of these reasons in this section. However, before doing so, it will be helpful to begin with a statement regarding why non-consensual participation is morally problematic. 


\section{1: Compulsory Military Participation}

Conscription - the compelling of individuals to participate in military operations without their consent - is the most widely recognized form on non-consensual military assembly. Moreover, it is the mode of assembly most often thought to be morally objectionable and is, therefore, the natural starting point for the present discussion. Indeed, if it is the case that the justice of a war is to be called into question based on the mode of assembly, then conscription seems like the best candidate for showing this to be so. This is because most liberal societies begin with a strong presumption against restricting or infringing upon the liberty of individuals, and conscription is a clear case of such an infringement. In addition to truncating personal liberty, conscription may also be objectionable due to the fact that it requires compelling an individual to fight for an end that is not her own while taking on the accompanying risk to life and limb. Thus, it is not simply an infringement on liberty, but an infringement that serves ends that the individual does not necessarily accept. In short, forced conscription of soldiers involves a morally objectionable contingency statement on the part of the government of the form, "Fight in this war, or pay the corresponding penalty," (where the penalty may be anything as innocuous as a fine or as severe as execution) and a contingency statement of this type is fundamentally and unjustifiably coercive. ${ }^{7}$ As far as restrictions on liberty and personal freedom are concerned, forced participation in military service may well be among the gravest of such violations, and this violation provides the basis for the best argument against conscription.

\footnotetext{
${ }^{7}$ For an instructive treatment of why this is the case, see Pallikkathayil (2011).
} 
Despite the straightforward violation of personal liberty, there are a number of reasons why one might still think that forced participation is justifiable. First, it might be claimed that contributing to the defense of a nation is simply an obligation that one has by virtue of being a citizen. William Galston defends this view, saying, "When society meets the standard of broad legitimacy, each citizen has a duty to do his or her fair share to sustain the social arrangements from which all benefit, and society is justified in using its coercive power when necessary to ensure the performance of this duty." $(2003, \mathrm{p}$. 3) If the obligations of citizenship include contributing to the defense of society, then the consentbased objection to conscription seems to fall by the wayside. However, there are good reasons to deny the argument from civic duty. For example, Michael Gorr argues that even if individuals have a political obligation to contribute to the defense of society, this obligation does not entail an obligation to perform military service. (1983, p. 82) Instead, all that follows is that citizens are obligated to contribute in some way, and this could be accomplished without direct military service. Additionally, it might be claimed that compulsory military service does not, in fact, constitute a fulfillment of civic duty insofar as performing one's duty involves doing so voluntarily. Pattison presses this point and suggests, further, that, at least in cases where the moral permissibility of the war is questionable, refusing military service may actually be a sign of good citizenship in a way that participating in the conflict would not. (2011, p. 146)

In addition to the civic duty defense of conscription, many have suggested that conscription is a morally permissible method of assembly because it more fairly distributes the burden of defending the state than does a voluntary force. (see Galston 2003) However, there are reasons to be skeptical of this argument as well. First, as Gorr suggests, this 
would simply not be true if the system of conscription were one which relied on a random selection method such as a lottery. In such a system, while everyone would have an equal chance of being selected, those who are actually selected would clearly bear a greater burden than those who were not selected, and this would not be the case in a system which relied on funding the military through taxation and staffing it through voluntary participation. (Gorr 1983) This problem might, of course, be avoided if the military relied on universal conscription, but this method of conscription has problems of its own. As Pattison suggests, in an unequal society universal service would, in fact, not be fair since some segments of the population receive far more social benefits than others and universal conscription would not require these segments to take on a proportionate amount of the burdens of national defense.

Offering a full account of the moral implications of conscription ${ }^{8}$ is well beyond the scope of this paper, but what has been said so far should be sufficient to show that there are, at the very least, serious doubts about whether or not the standard defenses of conscription can hold up under scrutiny. Moreover, given the strong presumption in favor of personal freedom, there is a heavy burden of proof on those who would deny premise (1) of the Argument from Consent, and this burden has not, in my opinion, been met.

\section{2: Manipulated vs. Purely Voluntary Participation}

From what has been said in the previous section, compulsory or coerced participation in the military seems to violate the Principle of Just Assembly. However, there is an important issue involving consent that remains to be explored. That issue is this: if, as

\footnotetext{
${ }^{8}$ For example, on a consequentialist theory of justice, a case might be made in favor of conscription if the destruction and loss of life that result from a war fought with an insufficient number of combatants was significant enough to outweigh the injustice done to the individual combatants when they are compelled to fight.
} 
premise (1) of the Argument from Consent holds, consent is required for Just Assembly, what are the conditions under which this consent can be considered genuine? In other words, if consent is a requirement of Just Assembly, how ought we to think about cases in which this consent is obtained through manipulative means and how might we distinguish these from cases of purely voluntary participation?

Roughly put, manipulation simply refers to the act of controlling another person for one's own ends. Extreme cases of manipulation involve the direct control of another person's thoughts or actions, ${ }^{9}$ but there can also be more subtle forms of manipulation. For example, an agent may be manipulated to act in a certain way by being led to believe, falsely, that a certain state of affairs that she desires to be realized will obtain if she does so act. 10

Instances of manipulation such as these are morally problematic because they undermine the agent's autonomy in important ways. In cases of manipulation, the manipulator uses a feature of an agent's psychological state in such a way as to cause the agent to perform some action for her own ends, an action that the agent would not otherwise perform and which is not among the agent's own ends. The manipulator uses the agent's motives against her and, in effect, takes control of the agent's ability to pursue her rational ends by using those ends for the manipulator's purposes. For all of these reasons, consent that is given as a result of manipulation cannot be considered genuine in the sense required by premise (1) of the Argument from Consent.

\footnotetext{
${ }^{9}$ Cases of brainwashing are paradigmatic of extreme instances of manipulation. Imaginary cases such as Harry Frankfurt's case of Smith and Jones serve as exemplars of this as well. See Frankfurt (1969).

${ }^{10}$ This is what Robert Kane (1996) refers to as "nonconstraining control." Similarly, an agent may be manipulated by having certain motives activated where they otherwise would not be. See Cave (2007) for examples of this.
} 
The relevance of this for the present discussion is that this sort of manipulation, I think, can be seen in various military recruitment strategies. Studies suggest that a number of factors influence the likelihood that individuals will enlist in the military. For example, the desire to do something for one's country consistently ranks among the top motivations for young people to join the armed forces. (Eighmey 2006) This being the case, military rhetoric which brandishes the "serve your country" language in an effort to recruit soldiers can be manipulative if the conflict for which individuals are recruited is such that the service advertised is misrepresented. In addition to the influence of the desire to serve, studies have shown that individuals who come from a disadvantaged background are far more likely to enlist in the military than those who come from a comparatively advantaged environment, (Elder et al. 2010) and the same is true of individuals who live in areas with a large military institutional presence. (Kleykamp, 2006) In cases like these, it must be asked whether or not the individuals who are enlisting are doing so as a result of acting from their own motives or whether these motives have been manipulated by other factors.

All of this suggests that there are a number of facts about civic life (e.g. pervasive attitudes glorifying war and military service, patriotism, socioeconomic factors) which might lend themselves to manipulating citizens into enlisting in the armed forces. The important question, then, is whether or not recruitment strategies exploit these to an extent that might constitute manipulation and some strategies seem do so.

This brings us to the important question regarding Just Assembly: How can we reliably distinguish between impermissible manipulation and permissible voluntariness? Given what has been said so far, it seems to me that two conditions must obtain in order for an individual's enlistment to be purely voluntary. It must be the case that the decision both 
proceeds from motives which genuinely belong to the individual and serves some end which the individual genuinely endorses. Therefore, when the state uses compulsion or manipulation to substitute its own motives or its own ends for those of the individual soldier, it has acted wrongly, and the individuals who enlist as a result of this action have been unjustly recruited. As John Christman puts the point,

[T]o be autonomous is to be one's own person, to be directed by considerations, desires, conditions, and characteristics that are not simply imposed externally upon one, but are part of what can somehow be considered one's authentic self. Autonomy in this sense seems an irrefutable value, especially since its opposite being guided by forces external to the self and which one cannot authentically embrace - seems to mark the height of oppression. (2011)

Coercion and manipulation undermine individual autonomy. They, quite literally, cause the individual to be moved by desires, motives, and aims that do not belong to her but which belong instead, in the case of military recruitment, to the state. It is only when the individual makes a fully autonomous decision to adopt the ends of a particular conflict as her own and is moved to do so by motives that genuinely belong to her that her recruitment may rightly be called just. This will, no doubt, sound far too strong for some. Nonetheless, I think that a strong autonomy requirement is needed in order to ensure just assembly, and military recruitment policy should be aimed at preserving the individual's capacity for autonomous decision-making to the greatest extent possible. Indeed, a nation's ability to fight a just war may depend on it.

There is an important objection in the offing that needs to be addressed, however. It might be claimed that a strong, individualist conception of autonomy like the one outlined here ignores the interrelatedness of citizens to one another and to government institutions, 
and, thus, that a relational view of autonomy is more suitable in this context. ${ }^{11}$ Such views of autonomy hold that what determines an individual's values and ends is, in part, a function of her social relations. ${ }^{12}$ If this sort of conception of autonomy is correct, then social institutions may influence the ends that an individual chooses to pursue without undermining the individual's autonomy. In the context of the present discussion, then, one might claim that in engaging in military recruitment, the government frames military participation in a particular way without objectionably violating the autonomy of citizens.

I won't offer an extended discussion of the debate between these conceptions of autonomy here but will, instead, conceded that a richer account of autonomy which goes beyond the individualist view may be better suited to handle some of the problems that I have discussed here. What this leaves us with is the problem of determining when manipulation has occurred and pure voluntarism has been undermined, or, when the framing effects of recruiting are such that they become morally problematic. Patriotic sentiment, for example, pervades the citizenry of many countries, and because of this, it may well be difficult to tell when enlistment occurs voluntarily as a result of an individual's sense of patriotism or when a government has used the individual's patriotism against her. Indeed, this may cause some to conclude that we can never know whether manipulation has occurred or not. In practice, this may be true, and it would be unreasonably burdensome to expect the state to guarantee the fully autonomous consent of each of its military members. Nonetheless, this epistemic difficulty does not pose a challenge for my view in principle. It may entail, in practice, however, that the state has a responsibility to

\footnotetext{
${ }_{11}$ I'm grateful to Eric Palmer for raising this point.

${ }^{12}$ See Barclay (2000) and Mackenzie (2008) for statements of this sort of view. See also Christman (2004) for some worries about this type of approach.
} 
implement institutional safeguards which help to mitigate the possible manipulation involved in recruiting enlistees.

This point requires some extended discussion. If the call for just assembly, in principle, is to have any application to the real world, then some treatment needs to be given of how it might be achieved in practice. There are at least two serious epistemic worries about the proposal that I am offering here. First, it would require that soldiers know a great deal about the aims and risks involved in a given conflict, and this is problematic both from the perspective of the soldier and the government. Second, it would require that the soldier have sufficient knowledge of her own motives (and their source) for participating in a given conflict. ${ }^{13}$ So, what institutional steps, if any, can be taken that will help to overcome these epistemic barriers to just assembly while still allowing a nation to carry out a war?

The first, and most obvious, step would be to institute a policy of transparency about (a) the nature and severity of the cause for war and (b) the foreseeable risk of participation. In short, this would be a policy of informed consent which would allow those deciding whether to enlist to do so with sufficient information. Moreover, this sort of information would not undermine the government's strategic ability in prosecuting the war. A further institutional safeguard would be the implementation of a policy which tones down the rhetoric used to "sell" the war to the citizenry. A policy against using highly moralized or inflammatory language would help to guard against manipulation worries like those expressed above and would go some way toward ensuring autonomous consent. To be sure, transparency and moderate rhetoric are not policies that are widely implemented

\footnotetext{
${ }^{13}$ My thanks to Eric Palmer and two anonymous referees for pressing me on this point.
} 
by governments, but that this is presently the case does not entail that it must be. If we care about justice in times of war these are reasonable, practicable demands that would bring us closer to achieving it.

The more difficult epistemic problem here, however, relates to information about the justice of a war. While it may be true, as I have just suggested, that information about the nature of the threat and the risk involved in war can be provided without undermining the government's ability to carry out the war, it is not at all obvious that the information needed to judge whether a war is just can be made available to soldiers as well. Plans must be carried out quickly, and information is often disseminated in pieces throughout the military hierarchy such that any given soldier may have only partial information. Moreover, if every member of the military possessed full information regarding military operations, then that information would be far less secure. It is also unlikely that soldiers or citizens in general will ever know the motives of their government in carrying out a war. These are all relevant pieces of information when judging the justice of a conflict, and it would be too much to demand that soldiers have such information or that governments offer it. Nevertheless, there must be some information that soldiers might have access to which would speak against the justice of a given conflict. One need not be a high ranking military official to have an informed opinion about the justice of a cause, for instance. Additionally, members of the military need not have full information about an operation in every case to know that their particular orders violate principles of jus in bello. In these cases, implementing a policy of selective conscientious objection may be a viable safeguard against practical epistemic objections to the differentiation of manipulated and purely 
voluntary participation. ${ }^{14}$ Such a policy which offered soldiers the opportunity to make a case for their conscientious objection based on the information that the soldier has would help to head off concerns about soldiers being manipulated into enlisting and subsequently being forced to participate in whatever war the state demands. The issue of selective conscientious objection, of course, applies to those who have already taken an oath to serve, and, so, it should require a relatively high burden of proof on the part of the soldier. A soldier's oath to protect and serve creates strong obligations that she must fulfill, and, so, a strong case must be made in order to override them. However, two points are important to keep in mind here. First, the oath to protect and serve does not create an obligation to act unjustly. In the same way that a doctor's oath to do no harm does not create an obligation to give treatment against a patient's will or that a lawyer's oath to defend her client does not create an obligation to destroy damaging evidence, a soldier's oath to protect and serve cannot obligate her to violate principles of justice in war. Second, an oath that is coerced or manipulated does not create any obligations for the soldier at all. So, the conditions specified above for genuine consent apply to career military members at the time that the oath is given.

One issue remains that requires discussion here. No mention has yet been made of soldiers who are hired to fight. In the past decade or so, a great deal of work has been done which focuses on the role of private military corporations (PMC's) in modern warfare and the implications that these corporations have on work in just war theory. While it is beyond the scope of this paper to give a comprehensive account of the moral issues surrounding

${ }^{14}$ For a defense of selective conscientious objection see Robinson (2009) or Navin (2013) 
PMC's, 15 it is worth noting a few important points here. First, since my aim is to make a case for the principle of just assembly on the basis of consent, there is nothing that is obviously troubling about PMC's since these corporations and their employees, presumably, consensually sign contracts to fight. Insofar as consent is given, mercenary forces are not problematic on the basis of the Argument from Consent that I am defending here. However, it is important to note that some of the same worries about manipulation apply to mercenary soldiers in much the same way as they apply to enlistees. Walzer is sensitive to this worry when he writes,

Our [positive] judgments [about the permissibility of mercenary war] are very different, however, if the mercenary armies are recruited (as they most often are) from among desperately impoverished men, who can find no other way of feeding themselves and their families except by signing up ... Then the battle becomes a 'circus of slaughter' in the midst of which no consensual discipline is possible, and those who die do so without ever having had a chance to live in another way. (1977, p. 27)

When mercenary forces are recruited from such conditions, the offer of payment for military combat may become coercive, 16 and if this is the case, then the Argument from Consent will apply to these soldiers as well.

Second, despite the fact that mercenary forces may meet the requirement of consent, there are other reasons that one might have for suspecting that this mode of assembly alters our jus ad bellum or jus in bello judgments in important ways. For example, James Pattison argues that the motives of PMC's are problematic insofar as it is morally suspect to cause the sort of harm involved in warfare for a purely financial motive. (2010,

\footnotetext{
${ }^{15}$ For a discussion of these, see Singer (2003); Lynch \& Walsh (2000); Heinze (2009); Fabre (2010); Pattison (2010)

${ }^{16}$ For more on coercive wage offers, see Zimmerman (1981)
} 
pp. 433-5). ${ }^{17}$ Motives matter for morality, he suggests, and financial gain is a troubling reason to appeal to when one is engaged in large-scale killing. On one way of understanding it, the ad bellum principle of Right Intention - which holds that a nation may go to war only if its intention is to defend the just cause - includes an appeal to motives as well. (Orend 2005) That is, in addition to intending to prevail in defense of the cause a nation must, on one understanding of the principle, do so without ulterior motive. If this is the case, then mercenary forces might fail to satisfy the principle of Right Intention.

A full treatment of the manner in, or the degree to, which privately contracted forces affect traditional just war principles cannot be given here. Insofar as my focus is on consent, I am willing to grant that PMC's may meet this criterion. However, there are deeply important moral issues surrounding their use, both in principle and in practice, which may well impact the justice of a war more generally.

\section{3: The Objection from Necessity}

To this point, I have been arguing as follows: one way of rejecting the Argument from Consent is to deny the truth of premise (1), and this might be accomplished by offering a defense of conscription. I have tried to show that there are serious problems with such defenses and that, given a strong presumption in favor of personal liberty, the burden of proof for the justice of conscription has not been met. I then argued that cases of manipulation pose worries similar to those posed by conscription, and that, as a result, Just Assembly requires voluntary enlistment in which the decision to participate in a conflict comes from motivations and in pursuit of ends that are authentically the agent's.

\footnotetext{
${ }^{17}$ It is important to note that Heinze (2009) rejects this argument.
} 
With all of this in mind, there is still one objection that might be leveled against premise (1) of the Argument from Consent by appealing to the notions of necessity or supreme emergency. Suppose, for example, that a nation is under an imminent threat of attack and that its military force lacks the personnel to successfully defend the nation from this threat. Suppose, moreover, that the threat is such that, if not deterred, the victim nation will face complete and thorough destruction. Would it be permissible for a nation to conscript citizens to aid in the defense of the polity in such a case? ${ }^{18}$ Or consider a case in which a nation faces the threat of genocide or mass enslavement. Would it then be permissible for a third party nation to intervene on their behalf? It seems to me that it must be conceded that in such cases it would not be unjust for a state to compel citizens to take up arms. However, as a practical matter it seems unlikely that compulsion would be necessary in such a case, as imminent danger of this sort is often sufficient to drive up voluntary enlistment. Nevertheless, given this exception in cases of necessity or supreme emergency, I propose that premise (1) of the Argument from Consent be amended to read as follows:

(1*) It is prima facie unjust to cause an individual to risk her life without her consent. ${ }^{19}$

This amendment does not, I think, make the preceding discussion of conscription, manipulation, and voluntarism any less forceful, and it removes the unreasonable implication that a state may not conscript soldiers even if the very existence of the state depends on doing so. Working out just how severe or imminent a threat must be in order to

\footnotetext{
18 These two features of the hypothetical case match what Walzer refers to as the seriousness and imminence requirement of supreme emergency, (1977, pp. 251-255). While Walzer's treatment of supreme emergency is not state-centric in the way that this hypothetical case is, these two criteria seem applicable in a similar way. ${ }^{19}$ Note that this alteration will require the conclusion of the argument to change as well. Thus, the conclusion might read: Therefore, it is prima facie unjust for a nation to engage in military conflict without the consent of the members of its military.
} 
override the consent requirement is a problem that still needs solving. Unfortunately, space considerations prevent me from doing so here.

\section{Section 3: The Connection between Just Assembly and Just War Principles}

Rather than refuting the Argument from Consent by denying premise (1), one may instead aim to show that the conclusion of the argument simply does not follow from its premises. That is, one may object that even if the premises are all true, there is no necessary connection between the fact that a state acts unjustly toward its citizens by failing to obtain their genuine consent and the justice of the war that it subsequently carries out. In this section, I will press back against this objection by attempting to elucidate the connection between principles of just war theory and the method that a nation uses to assemble its army. In order to do so, I will begin by examining the connection to jus ad bellum considerations and then turning to principles of jus in bello.

\section{2: Just Assembly and Jus ad Bellum}

Jus ad bellum, or the branch of just war theory which addresses the morality of engaging in war, has deep roots in western philosophy. I won't trace those roots here, but it will, nevertheless, be necessary to briefly consider several of the traditional jus ad bellum principles that are relevant to the present discussion. I will be mostly interested in treating the principles of Just Cause and Proportionality, but I will give some treatment to the principle of Legitimate Authority as well..$^{20}$

When considering the justice of engaging in war, the principle of Just Cause is arguably the most important of any of the jus ad bellum principles. This is simply the principle which says that in order for a war to be just, it must be fought in defense of a just

\footnotetext{
${ }^{20}$ For an excellent overview of jus ad bellum principles, see Coady (2012). For a more in-depth treatment of these, see Lee (2012).
} 
cause. While there may be other ways of interpreting precisely what makes a cause just, the most common formulation is one which says that the only such cause is self-defense or intervention in defense of another. As Michael Walzer puts it, "There must actually have been a wrong, and it must actually have been received... Nothing else warrants the use of force in international society - above all, not any difference of religion or politics." (1977, p. 62) As this principle relates to the method by which a military force is assembled, it should be clear that the presence of a just cause does not depend, in any fashion, on any considerations about assembly. The just cause is always external to the victim state, and so the cause may be just regardless of how the victim state's military was assembled. Conversely, the justice of the cause does not alter the requirement of just assembly. In other words, the presence of a just cause does not override the requirement of consent defended above (though the severity of the threat might do so, as I noted above). So, if the requirement of just assembly is to connect up with jus ad bellum principles, it must be by way of something other than the principle of Just Cause.

As I see it, one avenue by which the connection may be made is by reference to the principle of proportionality. The proportionality condition in jus ad bellum (I will say more about in bello proportionality below) states that the evil which results from engaging in war must be less than the evil that will result from not doing so. Precisely what is meant by this principle is a matter of debate. ${ }^{21}$ For example, it is often tempting to think about proportionality as a simple body count comparison (e.g. If we go to war, $x$ number of people will die. If we don't go to war, $y$ number of people will die. So, if $x$ is less than $y$, then the war meets the proportionality condition). However, this view of the goods and evils involved in

${ }^{21}$ For an excellent and thorough treatment of this debate, see Hurka (2005). 
war is surely too narrow. There are, for instance, good reasons to think that a nation's defending its sovereignty is a good result independent of any casualty calculations. Another way of thinking about the goods produced by a war is simply to think about them by reference to the war's cause. As Thomas Hurka puts it, "[T]he relevant goods are only those contained in the just causes. If a war has certain just aims, the goods involved in achieving those aims count toward its proportionality but goods incidental to them, such as boosting the economy or science, do not." (2005, p. 40) Likewise, there are good reasons to think that the evils involved in war go well beyond the casualties that war inevitably produces. It is surely an evil when a war results in the crippling of a nation's economy, the destruction of its natural resources, or the loss of valuable works of art, architecture, and similar culturally significant items. The interruption of a population's way of life is also a significant cost of war. So, in terms of both goods produced and evils caused, the principle of proportionality is concerned with far more than the number of deaths that occur. ${ }^{22}$

Given that the principle of proportionality is sensitive to a diversity of considerations, it seems to me that it must also be sensitive to facts about the circumstances under which a nation's armed force is assembled. Suppose, for example, that a nation whose army is assembled by means of forced participation is considering whether or not to engage in a conflict. Surely one of the considerations against going to war will be the potential loss of life of the members of that nation's military. However, my claim is that a further consideration against fighting is the harm which occurs at the time when the members of the nation's military are forced to fight. In other words, it is certainly a harm if a soldier is injured or killed in battle, but it is also a harm, in a very real sense, to force the

22 There is an additional question, of course, about how these goods and evils should be weighed against one another, but I will not make any attempt to defend any particular position in that regard. 
individual to participate in hostilities in the first place. Even if a soldier makes it out of battle unscathed (both physically and psychologically), she nonetheless suffers a harm if she is forced to give up or delay personal projects or opportunities that she judges important to her conception of what it means to live a good life. This harm is a direct result of the violation of personal liberty that occurs when a soldier is unjustly recruited into the military. There is, on the one hand, the potential harm of the battle field, and, on the other, the harm of interrupting one's life plans in order to go to battle. The former is always considered an important part of proportionality judgments, but my contention is that the latter deserves consideration in its own right. Moreover, there may be instances in which factoring the harm of unjust assembly into a proportionality calculation proves to be a decisive reason against engaging in a conflict.

There are important objections to this view that must be addressed. First, it might be claimed that this harm (of having one's life plans interrupted) is one that is universal during times of war regardless of the status of one's recruitment. This is indeed correct, but an important distinction must be made. In the case of voluntary participation, it is surely a negative consequence of war that a soldier must leave her family and interrupt her life to fight a war. However, this negative consequence is not properly a harm in the case of voluntary participation because the soldier has consented to it. A helpful analogy here might be that of a firefighter who is forced to forego a personal commitment in order to put out a fire. The firefighter surely risks her life, and it is surely a negative consequence of her profession that she is forced to forego commitments that may be important to her. However, this is not a harm to her since it is simply a natural consequence of a position that she consensually occupies. This is not the case, of course, for the unjustly assembled 
soldier. In the case of unjust assembly, the violation of the rights and liberties of combatants are indeed harms since such violations are not the result of a position that the soldier consensually occupies.

This same consideration may play an important role in wars of humanitarian intervention as well. The requirements for a just war of humanitarian intervention are much the same as those for wars of self-defense - there must be a reasonable chance of success, force must be the last resort to put an end to the humanitarian crisis, the intervening nation(s) must have legitimate authority and right intentions, and, importantly, the number of basic rights violations must be large enough to justify military intervention. The principle of just assembly alters ad bellum considerations for wars of humanitarian intervention, then, in much the same way as it does for wars of self-defense. It requires that we weigh, among the many harms caused by armed intervention, the harm done to unjustly assembled soldiers, and, in some cases, it may be that these harms affect the proportionality calculation in significant ways. ${ }^{23}$

A second objection which must be addressed is this: a nation fighting a just war is doing so, presumably, in order to defend innocent people from being killed and from having their rights violated. Therefore, these rights violations would take place regardless of whether the soldiers were unjustly assembled or not. This is an important objection, and it sheds light on an important feature of the connection between just assembly and ad bellum proportionality, namely, that what is entailed by the Argument from Consent is only that these harms play a role in proportionality calculations and not that the harm of unjust

\footnotetext{
${ }^{23}$ James Pattison has suggested a further constraint for wars of humanitarian intervention, namely, that engaging in the war must be representative of the wishes of the people of the intervening nation. (2007) I'll not discuss this proposal in any detail here, but if it is correct then there may be an additional layer to the sort of consent needed in these wars.
} 
assembly is a decisive just war principle. Thus, what these arguments warrant is, perhaps, a weakened statement of the principle along the following lines:

\section{Principle of Just Assembly*}

A justly assembled armed force is a central, but at times defeasible, requirement for a nation's ability to engage in a just war.

This version of the principle, though considerably weaker than the original, is still a departure from traditional just war doctrine because it identifies a new constraint on military activity insofar as the harms discussed here are not traditionally factored in to just war doctrine at all. Moreover, given how contentious judgments regarding the moral permissibility of war often are, a broader interpretation of traditional principles which includes a sensitivity to the recruitment status of soldiers may be sufficient to tip the scales of proportionality calculations in many cases.

In addition to having an impact on the principle of proportionality, a principle requiring just assembly might be thought to have serious implications for the traditional requirement of Legitimate Authority. This principle, traditionally understood, states that wars may only be declared and carried out if this is done by a legitimate authority, i.e. some group or person with political authority of some kind. Thus, the central idea is that only government officials with legitimate political authority may permissibly start a war with another nation. However, if it is true that the only justly assembled military force is one which ensures (or takes appropriate steps to ensure) the consent of its military members, then an additional source of authority is admitted into deliberations about war - the authority that the soldier has over herself. Insofar as each soldier has the authority to decide whether or not to participate in a given conflict, there is a sense in which the collective authority of the combatants is required before any declaration of war on the part 
of state officials can carry any weight. The argument for this connection might be formalized as follows:

(1) The principle of Legitimate Authority holds that war may only be declared by those with legitimate political authority to do so.

(2) A declaration of war is meaningless (or at least ineffectual) without an armed force to back it.

(3) The authority to decide to participate (or not) in a conflict lies in the military members.

(4) Therefore, the collective authority of the military is precondition for the meaningful declaration of war.

These considerations clearly do not alter the fact that formal declarations of war must come from political authority, but they do, I think, show that this authority is rather impotent if it is not backed by the authority of the combatants.

The above shows that there is at least some connection between these principles of jus ad bellum and the manner in which an armed force is assembled. This is sufficient to show that the Argument from Consent is successful. That is, it shows that the claim that the argument lacks a logical connection between the premises and the conclusion is, in fact, false. However, the argument will be much stronger if a similar connection can be shown to obtain between the mode of assembly and principles of jus in bello as well.

\section{3: Just Assembly and Jus in Bello}

The link between a requirement of just assembly and the traditional principles of jus in bello is decidedly murkier than the connection it bears to ad bellum principles. Nevertheless, there does seem to be some considerations about assembly that might be able to inform the way we think about jus in bello. I will outline these considerations only briefly here. 
Generally speaking, there are two significant principles that define jus in bello, and these are the principles of discrimination and proportionality. ${ }^{24}$ The principle of discrimination (also referred to as the principle of noncombatant immunity) simply states that soldiers must refrain from killing civilians. The prohibition on killing civilians is not, however, unconditional or absolute. The principle allows for civilian casualties so long as these are unintended (but perhaps foreseen, or foreseeable) side-effects of legitimate military activities. In other words, noncombatants may permissibly be killed, but they may never be permissibly targeted. This prohibition leads, in large part, to the in bello iteration of the proportionality principle. Proportionality, in this context, requires that the amount of damage and loss of civilian life must be proportional to the importance of the military target. For example, it may be permissible to bomb a military target in a densely populated area that could foreseeably kill a large number of civilians if the destruction of that target could, say, potentially bring about the end of the conflict. However, the same bombing may not be permissible if the target were, for instance, a small munitions cache the loss of which would have little perceptible impact on the war's outcome.

Given these two in bello principles, it may seem false to say that discriminating between combatants and civilians and carrying out proportionate military actions depend in any way on the manner in which an army is assembled. However, such a claim seems premature. To see why, it will be helpful to consider the connection between principles of jus ad bellum and those of jus in bello. In recent years, Jeff McMahan has compellingly

\footnotetext{
${ }^{24}$ It may be worth noting that certain other principles are often included in jus in bello as well. The most important of these is the principle of necessity which states that force may only be used if it is necessary for achievement of an objective. Other principles may be included as well. For example, it is often asserted that jus in bello requires nations to refrain from using weapons or tactics that are mala in se, or evil in themselves. Other principles may be included as well, but these are largely secondary concerns and won't be treated in the discussion here.
} 
defended a thesis about the connection of these two sets of principles that departs dramatically from the traditional understanding of the two.

The traditional interpretation of the relationship between ad bellum and in bello principles is that the two are logically independent. As Walzer says, regarding the distinction of the two, "We draw a line between the war itself, for which soldiers are not responsible, and the conduct of the war, for which they are responsible, at least within their own sphere of activity." (1977, pp. 38-9) This view is one which regards soldiers on both sides of a conflict as moral equals who possess an equal right to kill one another in the course of battle. However, McMahan rejects this conception of the ad bellum/in bello distinction and argues that in bello principles must be considered in light of the determinations made with respect to the justice of the war. So, he claims, combatants are not moral equals insofar as those who are fighting in defense of a just cause have not made themselves liable to be attacked, and those fighting in defense of an unjust cause, therefore, do not have an equal right to kill. Moreover, McMahan says, "the criterion of liability to attack in war is moral responsibility for an objectively unjustified threat of harm." (2009, p. 35) I do not wish to enter into this debate except to say that I think McMahan's position is essentially correct. ${ }^{25}$ Rather, what I am interested in is considering whether or not McMahan's basic insight can inform our views on the connection between assembly and jus in bello principles. That central insight is that the status of soldiers has an influence on the moral judgments we make regarding their behavior and how they may be permissibly

\footnotetext{
${ }^{25}$ Given the revisionary nature of McMahan's view, my reliance on it here might be unsatisfying for some readers. Unfortunately a full defense of this sort of view would be beyond the scope of this paper. Nevertheless, the basic claim that McMahan proposes has been defended by a number of other theorists in recent literature. See, for example, Fabre (2009), Rodin (2002), or McPherson (2004).
} 
treated. Insofar as the circumstances of their recruitment constitute at least a part of their moral standing, those circumstances ought to play a role in a number of in bello judgments.

McMahan is very clear that he does not regard the conditions under which an individual joins a military force to excuse that individual from liability to attack if she is engaged in an unjust war. To this end, he says, "All unjust combatants who are actually or potentially engaged in fighting are aware that they are intentionally attacking some people, risking harming others, or at least are committed to doing so ... What this means is that there is a basis for liability in virtually all unjust combatants." (2009, pp. 182-3) He also says very clearly that he does not think that unjust combatants are able to meet the requirements of either in bello proportionality or discrimination in war.

So what might a principle of just assembly add to jus in bello considerations beyond this? As I see it, what is added, is a proportionality consideration with respect to the risk that a nation may permissibly ask its own military members to assume. Jus in bello requirements govern, almost exclusively, the obligations that soldiers have to refrain from acting toward enemy combatants and civilians in various ways, but they, so far as I can tell, have never been construed to limit the treatment by a nation of its own soldiers. Even without such a principle, a nation has a strategic incentive and moral obligation not to ask its military members to assume unnecessary risks, but this obligation is not one that is considered as falling within the confines of jus in bello. The in bello variety of proportionality simply holds that soldiers must take care not to cause disproportionate harm to civilians, but if we take seriously the notion that a just war requires justly assembled soldiers, then it seems that we must conclude that those giving orders to soldiers who have not consented to risk their lives are bound by jus in bello principles to 
treat the lives of the soldiers as having the same weight, so to speak, as civilian lives for the purposes of in bello evaluations of the proposed course of action. The reason for this is that unjustly assembled soldiers have not made themselves liable to the sorts of risks that they would be asked to assume in the course of war, and this is so even if they fight in defense of a just cause.

To see how this would impact proportionality evaluations, consider the following example: suppose that a military official is trying to decide whether or not to pursue a ground attack on a purely military target with no possibility of civilian casualties. The official knows that the course of action in question would endanger the lives of fifty of his soldiers, but the target is important enough that this danger might (on a traditional understanding) be justified. However, another way of achieving the same aim might be to launch an aerial attack in which none of his soldiers are killed but fifty civilians are. However, the target is not important enough to justify this level of civilian casualty. So, traditional proportionality considerations would recommend launching the ground attack. My contention, however, is that if the official's soldiers have been unjustly assembled, then the risk to their lives ought to be counted with the same weight for proportionality calculations as the lives of civilians, and, so, neither attack would be justifiable.

So, there seems to be at least some reason, I think, to conclude that a principle of just assembly might be directly connected to the principles of jus in bello. While such a connection is not necessary to establish the need for the requirement given the connection to jus ad bellum demonstrated above, it nevertheless gives us a further reason to think that assembly matters for just war considerations. What has been said so far gives ample reason to conclude that present just war considerations are incomplete in an important way and 
that before we can begin thinking about war, we must first think about how we may permissibly go about preparing for war. Doing so will require greater clarity about precisely what it means for a military force to be justly assembled.

\section{Section 4: Conclusion}

Given what has been said so far, the revised Argument from Consent can be stated as follows:

(1) It is prima facie unjust to cause an individual to risk her life without her consent.

(2) If a nation engages in military conflict, it risks the lives of its military members.

(3) If a nation's military members do not consent to participate in a conflict, then by engaging in said conflict the nation risks the lives of its military members without their consent.

(4) Therefore, it is prima facie unjust for a nation to engage in military conflict without the consent of the members of its military.

To this point, I have defended this argument by claiming that attempts to deny premise (1) are unsuccessful. Military forces that are assembled by way of compelling or manipulating the participation of their soldiers do not meet the requirements of justice, and in order for these requirements to be met, nations must take steps to ensure that the decision to enlist is one that flows from motivations and serves ends that the enlistee genuinely accepts as her own and is thus the product of the enlistee's autonomous agency.

I have also aimed to defend the argument by making explicit the relationship that holds between the conditions under which an army is assembled and the principles of just war theory more broadly. These conditions have a direct impact on both ad bellum and in bello proportionality as well as broadening the principle of Legitimate Authority so as to include the authority that each combatant has over herself and which is a prerequisite for meaningful declarations of war. One primary goal of this paper has been to draw attention to a feature of war that, I believe, has been regrettably neglected. Given the high stakes 
involved in military conflict, attending to the recruitment status of the men and women who fight strikes me as extremely important, and what I have said here has been aimed at demonstrating why this is the case. Much work still remains, but it is my hope that the arguments of this paper will provide a foothold for new work on just assembly.

\section{BIBLIOGRAPHY}

Barclay, Linda. "Autonomy and the Social Self." In Relational Autonomy: Feminist Perspectives on Autonomy, Agency, and the Social Self. Edited by Catriona Mackenzie and Natalie Stoljar, 52-71. New York: Oxford University Press, 2000.

Bazargan, Saba. "Moral Equality of Combatants." The International Encyclopedia of Ethics. Blackwell Publishing, 2013. DOI: 10.1002/9781444367072.wbiee343

Cave, Eric M. "What's Wrong with Motive Manipulation?" Ethical Theory and Moral Practice. Vol. 10, No. 2. (2007): 129-144.

Coady, C.A.J. "War and Intervention." In Issues in Political Theory, edited by Catriona McKinnon, pp. 56-79. New York: Oxford University Press, 2012.

Christman, John. "Autonomy in Moral and Political Philosophy." In The Stanford Encyclopedia of Philosophy. Edited by Edward N. Zalta. (2011). Available at http://plato.stanford.edu/entries/autonomy-moral/ . "Relational Autonomy, Liberal Individualism, and the Social Constitution of Selves." Philosophical Studies. Vol. 117. (2004): 143-164.

Eighmey, John. "Why Do Youth Enlist? Identification of Underlying Themes" Armed Forces and Society. Vol. 32, No. 2. (2006): 307-328. 
Elder, Glen H., Lin Wang, Naomi J. Spence, Daniel E. Adkins, Tyson H. Brown. "Pathways to the All-Volunteer Military." Social Science Quarterly. Vol. 91, No. 2. (2010): 455-475.

Fabre, Cecile. "Guns, Food, and Liability to Attack in War." Ethics. Vol. 120. (2009): 36-63. . "In Defence of Mercenarism." British Journal of Political Science. Vol. 40, No. 3. (2010): 539-559.

Frankfurt, Harry G. "Alternate Possibilities and Moral Responsibility." 1969. In Free Will, 2nd Ed., 167-176. Edited by Gary Watson. New York: Oxford University Press, 2003.

Galston, William A. "A Sketch of Some Arguments for Conscription." Philosophy \& Public Policy Quarterly. Vol. 23, No. 3. (2003): 1-7.

Gorr, Michael. "Some Arguments against Peacetime Conscription." Social Theory \& Practice. Vol. 9, No. 1. (1983): 73-84.

Heinze, Eric. "Private Military Companies, Just War, and Humanitarian Intervention." In Ethics, Authority, and War: Non-State Actors and the Just War Tradition. 123-150. Edited by Eric Heinze and Brent Steele. New York: Palgrave Macmillan, 2009.

Hurka, Thomas. "Proportionality in the Morality of War." Philosophy \& Public Affairs. Vol. 33, No. 1. (2005): 34-66.

Kane, Robert. The Significance of Free Will. New York: Oxford University Press, 1996.

Kleykamp, Meredith A. "College, Jobs, or the Military? Enlistment During a Time of War." Social Science Quarterly. Vol. 87, No. 2. (2006): 272-290.

Lee, Steven P. Ethics and War: an Introduction. New York: Cambridge University Press, 2012.

Lynch, Tony and A. J. Walsh. "The Good Mercenary?” The Journal of Political Philosophy. Vol. 8, No. 2. (2000): 133-153. 
Mackenzie, Catriona. "Relational Autonomy, Normative Authority, and Perfectionism." Journal of Social Philosophy. Vol. 39, No. 4. (2008): 512-533.

McMahan, Jeff. Killing in War. New York: Oxford Clarendon Press, 2009.

McPherson, Lionel. "Innocence and Responsibility in War." Canadian Journal of Philosophy. Vol. 34, No. 4. (2004): 485-506.

Navin, Mark. "Sincerity, Accuracy and Selective Conscientious Objection." Journal of Military Ethics. Vol. 12, No. 2. (2013): 111-128.

Orend, Brian. "War." In The Stanford Encyclopedia of Philosophy. Edited by Edward N. Zalta. (2005). Available at http://plato.stanford.edu/entries/war/

Pallikkathayil, Japa. "The Possibility of Choice: Three Accounts of the Problem with Coercion." Philosopher's Imprint. Vol. 11, No. 16. (2011).

Pattison, James. "Deeper Objections to the Privatisation of Military Force." The Journal of Political Philosophy. Vol. 18, No. 4. (2010): 425-447.

. "Representativeness and Humanitarian Intervention." Journal of Social Philosophy. Vol. 38, No. 4. (2007): 569-587.

. "The Legitimacy of the Military, Private Military and Security Companies, and Just War Theory." European Journal of Political Theory. Vol. 11, No. 2. (2011): 131-154.

Reichberg, Gregory M. "Just War and Regular War: Competing Paradigms," In Just and Unjust Warriors: The Moral and Legal Status of Soldiers. 193-213. Edited by David Rodin and Henry Shue. New York: Oxford University Press, 2008.

Robinson, Paul. "Integrity and Selective Conscientious Objection." Journal of Military Ethics. Vol. 8, No. 1. (2009): 34-47.

Rodin, David. War and Self-Defense. Oxford: Oxford University Press, 2002. 
Singer, Peter. Corporate Warriors: The Rise of the Privatized Military Industry. Ithaca, NY: Cornell University Press, 2003.

Steiner, Hillel. "Self-Ownership and Conscription." In The Egalitarian Conscience: Essays in Honour of G. A. Cohen, 88-101. Edited by Christine Sypnowich. Oxford: Oxford University Press, 2006.

Walzer, Michael. Just and Unjust Wars: A Moral Argument With Historical Illustrations. New York: Basic Books, 1977.

Zimmerman, David. “Coercive Wage Offers.” Philosophy and Public Affairs. Vol. 10, No. 2. (1981): 121-145. 